\title{
Stres berhubungan dengan atensi pada siswa sekolah menegah atas
}

\author{
Nurhasanah $^{1}$, Meiyanti $^{2}$
}

\begin{abstract}
ABSTRAK
\section{LATAR BELAKANG}

Atensi merupakan komponen kecil dalam tahap memori saat seseorang melakukan proses berpikir. Bila terdapat gangguan pada atensi, maka seseorang akan sulit untuk menerima atau mempelajari hal yang baru. Atensi dipengaruhi oleh berbagai situasi, salah satunya adalah stres. Stres merupakan masalah umum yang terjadi dalam kehidupan manusia dan menjadi bagian hidup yang tidak dapat dielakkan. Siswa sekolahpun dapat mengalami stres yang dapat berpengaruh terhadap atensi dan mempengaruhi tingkat prestasi. Tujuan penelitian ini untuk mengetahui adanya hubungan stres dengan atensi pada siswa sekolah menengah atas.

\section{METODE}

Penelitian ini merupakan studi observasional dengan desain cross sectional yang mengikusertakan 173 siswa sekolah menengah atas. Responden diperoleh dengan teknik cluster sampling. Stres diukur dengan menggunakan perceive stress scale dan atensi diukur dengan menggunakan digit span test. Analisis data menggunakan uji Chi-square untuk mengetahui hubungan antara stres dengan atensi.
\end{abstract}

\section{HASIL}

Didapatkan jumlah responden sebanyak 173 orang dengan $26 \%$ siswa dengan tingkat atensi yang buruk dan $28.3 \%$ yang mengalami stres. Dari hasil analisis bivariat terdapat hubungan yang signifikan antara stres dengan atensi pada siswa sekolah menengah atas $(\mathrm{p}=0.000)$.

\section{KESIMPULAN}

Terdapat hubungan yang signifikan antara stres dengan atensi pada siswa sekolah menengah atas.

Kata kunci: stres, atensi, siswa, sekolah menengah atas

\author{
${ }^{1}$ Program Studi Kedokteran, \\ Fakultas Kedokteran Universitas \\ Trisakti, Indonesia \\ ${ }^{2}$ Departemen Farmakologi dan \\ Farmasi Kedokteran, Fakultas \\ Kedokteran Universitas Trisakti, \\ Indonesia
}

\section{Korespondensi:}

Meiyanti

Departemen Farmakologi dan Farmasi Kedokteran, Fakultas Kedokteran Universitas Trisakti, Indonesia

Jalan Kyai Tapa No. 260, Grogol, Jakarta Barat

Email: meiyanti@trisakti.ac.id; meiyanti_suhardi@yahoo.com

J Biomedika Kesehat 2020;3(1):3-7 DOI: 10.18051/JBiomedKes.2020. v3.3-7

pISSN: 2621-539X / eISSN: 2621-5470

Artikel akses terbuka (open access) ini didistribusikan di bawah lisensi Creative Commons Attribution 4.0 International (CC-BY 4.0) 


\section{ABSTRACT}

\section{Stress is related to attention in senior high school students}

\section{BACKGROUND}

Attention is a small component in the memory stage when someone does the thought process. If there is interference with attention, then someone will be difficult to accept or learn something new. Attention is influenced by various situations, one of which is stress. Stress is a common problem that occurs in human life and become an inevitable part of life. Even school students can experience stress that can affect attention and affect achievement levels. The purpose of this study was to determine the relationship of stress with attention in high school students.

\section{METHODS}

This study was an observational study with a cross sectional design that included 173 high school senior high school students. Respondents were obtained by cluster sampling technique at high schools. Stress is measured using perceive stress scales and attention is measured using the digit span test. Chi-square test was used to know relationship between stress and attention.

\section{RESULT}

The total of the respondents 173 subjects with $26 \%$ of it has poor attention and $74 \%$ of it has stress. There is significance relationship between stress and attention in senior high school students from bivariate analysis $(\mathrm{p}=0.000)$.

\section{CONCLUSION}

There is significance relationship between stress and attention in senior high school students.

Keywords: stress, attention, student, senior high schools

\section{PENDAHULUAN}

Atensi merupakan proses kognitif yang melibatkan berbagai macam aspek psikologi dan neurologis. Atensi didefinisikan sebagai pemusatan pikiran secara jelas dan tajam terhadap satu objek. Atensi merupakan salah satu bagian atau komponen kecil dalam tahapan memori disaat melakukan proses berpikir. Esensi dariatensiadalah fokalisasi, konsentrasi dan kesadaran. Komponen atensi terdiri dari alerting, orienting dan executive control yang berbeda secara fungsional maupun anatomikal. Riwayat cedera kepala, stres, kualitas tidur dan obat-obatan merupakan faktor yang dapat mempengaruhi atensi seseorang. ${ }^{(1,2)}$

Sebuah penelitian di Surakarta memperlihatkan bahwa $48.25 \%$ remaja memiliki kemampuan konsentrasi rendah. ${ }^{(3)}$ Konsentrasi yang rendah ini akan mempengaruhi kemampuan siswa untuk menangkap dan mengolah pelajaran, hal ini akan mempengaruhi prestasi belajar. ${ }^{(2,3)}$

Konsentrasi yang rendah dapat disebabkan oleh adanya stres, kondisi lingkungan sekitar, kondisi kesehatan, kualitas tidur maupun penggunaan obat-obatan. Stres merupakan respon keseimbangan tubuh dan pikiran terhadap perubahan dalam hidup, baik maupun buruk, perubahan terhadap situasi yang baru atau berbeda dari sebelumnya, bertambah atau berkurangnya orang-orang dalam kehidupan, dan perubahan perasaan dalam diri tiap individu. ${ }^{(4,5)}$ Ada hasil penelitan yang memperlihatkan tidak terdapat hubungan antara stres dengan atensi. ${ }^{(6)}$ Penelitian lain memperlihatkan hubungan stres dengan konsentrasi. ${ }^{(7,8)}$

Pentingnya atensi pada siswa di bidang pendidikan dan hasil penelitian yang masih saling bertentangan antara stres dengan atensi, mendorong penulis untuk meneliti hubungan stres dengan atensi pada siswa sekolah menengah atas.

\section{METODE}

Penelitian ini menggunakan desain analitik observasional dengan pendekatan cross sectional. Pengambilan sampel dilakukan pada bulan Oktober-Desember 2018. Populasi terjangkau pada penelitian ini adalah semua siswa di dua sekolah menengah atas swasta yaitu SMA X, Jakarta Utara dan SMA Y, Jakarta Barat. Responden yang berpatisipasi dalam penelitian ini 173 siswa, berusia 15-17 tahun, tidak sedang mengonsumsi obat-obatan, tidak memiliki riwayat cedera otak dan tidak mengalami gangguan cemas. Pemilihan sampel dilakukan dengan metode simple random sampling untuk pemilihan sampel di masing-masing kelas yang terpilih. Data stres diperoleh melalui pengisian kuesioner Perceived Stress Scale (PSS) dan dilakukan tes digit span untuk memperoleh skor atensi. Analisis data bivariat hubungan stres dan atensi dilakukan dengan uji Chi-square dengan tingkat kemaknaan 
95\%. Penelitian ini telah lulus uji kaji etik dari Fakultas Kedokteran Trisakti dengan No 138/ KEF-FK/VIII/2018.

\section{HASIL}

Tabel 1. Karakteristik subjek $(n=173)$

\begin{tabular}{lc}
\hline Karakteristik & $\begin{array}{c}\text { Jumlah } \\
\mathbf{n}(\%)\end{array}$ \\
\hline Jenis kelamin & $102(59 \%)$ \\
Laki-laki & $71(41 \%)$ \\
Perempuan & \\
Usia & $56(32.4 \%)$ \\
15 & $49(28.3 \%)$ \\
16 & $68(39.3 \%)$ \\
17 & \\
Kelas & $59(34 \%)$ \\
X & $57(33 \%)$ \\
XI & $57(33 \%)$ \\
XII & \\
Stres & $49(28.3 \%)$ \\
Ya & $124(71.7 \%)$ \\
Tidak & \\
Atensi & $128(74 \%)$ \\
Baik & $45(26 \%)$ \\
Buruk & \\
\hline
\end{tabular}

Karakteristik subjek disajikan pada Tabel 1. Berdasar tabel tersebut, jenis kelamin responden tidak berbeda $(59 \%$ berjenis kelamin laki-laki dan $41 \%$ berjenis kelamin perempuan). Responden juga tersebar merata antara usia 15, 16, dan 17 tahun, juga untuk persebaran responden berdasarkan tingkatan kelas X, XI, dan XII. Berdasarkan hasil pengukuran kuesioner PSS dan digit span, didapatkan bahwa siswa yang mengalami stres mencapai $28.3 \%$ dan siswa yang memiliki atensi buruk mencapai $26 \%$.
Berdasarkan Tabel 2, hasil analisis bivariat Chi-square menunjukkan hubungan stres dengan atensi di dapatkan nilai $\mathrm{p}=0.000$, disimpulkan terdapat hubungan yang signifikan antara stres dengan atensi. Sebanyak 102 siswa dengan jenis kelamin laki-laki menjadi subjek penelitian, dari jumlah ini diperoleh 26 siswa (25.5\%) memiliki atensi yang buruk. Uji analisis bivariat menyimpulkan tidak terdapat hubungan antara jenis kelamin dengan atensi $(p=0.851)$. Tingkat atensi buruk tertinggi berada di tingkat kelas X sebanyak 18 siswa (30.5\%). Pada hasil uji Chi-square disimpulkan tidak terdapat hubungan antara kelas dengan atensi $(p=0.509)$.

\section{PEMBAHASAN}

Prevalensi stres pada studi ini sebesar $28.3 \%$, angka ini lebih rendah dibandingkan penelitian sebelumnya dengan prevalensi stres sebesar $48.4 \% .{ }^{(9)}$ Perbedaan hasil penelitian ini mungkin dikarenakan perbedaan lokasi penelitian dan tingkat pendidikan. Lingkungan merupakan salah satu sumber stressor pada seseorang, di mana lingkungan mempunyai pengaruh yang sangat besar bagi siswa.

Hasil penelitian ini memperlihatkan tidak terdapat hubungan antara tingkat kelas dengan stres pada siswa SMA yang sejalan dengan peneliti sebelumnya. ${ }^{(10)}$ Pada hasil penelitian ini menyebutkan adanya faktor stres yang diakibatkan oleh hubungan teman sebaya. Hal ini berbeda dengan hasil studi sebelumnya yang memperlihatkan terdapat hubungan antara tingkat

Tabel 2. Stres, jenis kelamin dan tingkat kelas dengan atensi

\begin{tabular}{|c|c|c|c|c|}
\hline \multirow[b]{2}{*}{ Variabel } & \multicolumn{3}{|c|}{ Atensi } & \multirow{2}{*}{ p* } \\
\hline & $\begin{array}{c}\text { Atensi buruk } \\
\text { n (\%) } \\
\end{array}$ & $\begin{array}{c}\text { Atensi baik } \\
\text { n (\%) } \\
\end{array}$ & $\begin{array}{l}\text { Total } \\
\text { n (\%) } \\
\end{array}$ & \\
\hline \multicolumn{5}{|l|}{ Stres } \\
\hline $\mathrm{Ya}$ & $26(53.1)$ & $23(46.9)$ & $49(100)$ & 0.000 \\
\hline Tidak & $19(15.3)$ & $105(84.7)$ & $124(100)$ & \\
\hline \multicolumn{5}{|l|}{ Jenis kelamin } \\
\hline Laki-laki & $26(25.5)$ & $76(75.5)$ & $102(100)$ & 0.851 \\
\hline Perempuan & $19(28.6)$ & $52(73.2)$ & $71(100)$ & \\
\hline \multicolumn{5}{|l|}{ Tingkat kelas } \\
\hline$X$ & $18(30.5)$ & $41(69.5)$ & $59(100)$ & 0.509 \\
\hline XI & $12(21.2)$ & $45(78.9)$ & $57(100)$ & \\
\hline XII & $15(26.3)$ & $42(73.7)$ & $57(100)$ & \\
\hline
\end{tabular}

*Uji Chi-square 
kelas dengan stres. ${ }^{(11)}$ Perbedaan hasil penelitian ini didukung oleh beberapa faktor-faktor yang dapat mempengaruhi situasi stres. Stres yang didapatkan bisa bervariasi tergantung jenis stressor, waktu terpapar stressor dan keparahan dari stressor itu sendiri. ${ }^{(4,12,13)}$ Hasil penelitian ini menunjukkan bahwa tingkat kelas yang mengalami stres lebih banyak berada di tingkat kelas XI. Siswa pada tingkat kelas XI memiliki faktor stres terutama disebabkan oleh kesibukan yang dialami seharihari selama kegiatan belajar seperti ulangan harian, tugas sekolah maupun tugas mandiri, ulangan umum dan faktor ekonomi keluarga.

Hasil penelitian ini memperlihatkan tidak terdapat hubungan antara jenis kelamin dengan stres pada siswa SMA yang sesuai dengan hasil penelitian sebelumnya, ${ }^{(14)}$ di mana atensi pada laki-laki maupun perempuan memiliki peluang yang sama untuk tetap konsentrasi. Beberapa faktor seperti usia, minat atau bakat, kebutuhan dan latihan konsentasi akan berpengaruh pada atensi seseorang. Pada usia tua terjadi penurunan anatomi dan penurunan fungsional otak. Pada orang yang terlatih memberikan atensi maka seseorang tersebut memiliki tingkatan atensi yang lebih baik begitu juga sebaliknya. Pada seseorang akan lebih mudah menempatkan atensinya pada stimulus yang mereka sukai atau dianggap penting untuk mereka. ${ }^{(12,14)}$

Penelitian ini yang memperlihatkan hubungan antara tingkat kelas dengan atensi pada siswa SMA yang sejalan dengan hasil penelitian sebelumnya, ${ }^{(14)}$ dan terdapat 2 faktor yang mempengaruhi atensi yaitu faktor internal dan faktor eksternal. Faktor internal merupakan faktor yang berasal dari dalam diri sendiri berupa minat belajar yang rendah atau kondisi kesehatan. Kondisi kesehatan yang menurun dapat menyebabkan penurunan atensi. Faktor eksternal seperti hubungan antar teman, sosio budaya dan tingkat kelas dapat juga mempengaruhi tingkat atensi. Banyaknya faktor yang dapat mempengaruhi atensi maka perlu diketahui cara meningkatkan atensi. Ada beberapa cara untuk meningkatkan atensi yang dapat dicoba untuk dilakukan seperti membuat kerangka waktu yang jelas, membuat perencanaan penyelesaian tugas, menciptakan kondisi linkungan belajar yang kondusif, dan motivasi.
Hasil penelitian ini memperlihatkan hubungan antara stres dengan atensi pada siswa SMA sejalan dengan hasil penelitian sebelumnya. Stres dapat menimbulkan kesulitan dalam konsentrasi, memori dan kemampuan memecahkan masalah. Selain itu juga dinyatakan bahwa bahwa stres berpengaruh terhadap atensi karena dapat merusak kortek prefrontal (PFC) pada pemrosesan atensi seseorang. ${ }^{(16)}$

Hasil penelitian ini berbeda dengan hasil penelitian sebelumnya yang menyebutkan tidak terdapat hubungan yang signifikan antara stres dengan atensi. ${ }^{(6)}$ Rendahnya kualitas prestasi belajar siswa sebagian besar disebabkan oleh lemahnya kemampuan anak didik untuk dapat melakukan atensi. Oleh karena itu, siswa perlu mencari keadaan atau situasi yang kondusif agar tetap fokus pada hal yang sedang dilihat atau dipikirkan sehingga dapat berkonsentrasi secara penuh. Tetap fokus atau berkonsentrasi secara terus-menerus sangat penting untuk memperoleh arus informasi secara baik dalam situasi formal maupun informal. ${ }^{(17-19)}$

Penelitian ini masih memiliki keterbatasan yaitu, sampel penelitian dilakukan hanya di dua lokasi sekolah dengan waktu penelitian yang relatif singkat. Faktor perancu lain seperti faktor biologis, kebiasan, sosiopsikologis dan sikap tidak dilakukan analisis. Implikasi klinis dari penelitian ini adalah banyak faktor yang dapat mempengaruhi tingkat stres pada siswa dan hal ini akan mempengaruhi atensi yang dapat menimbulkan penurunan prestasi belajar siswa.

\section{KESIMPULAN}

Prevalensi siswa yang mengalami stres dan atensi buruk adalah $28.3 \%$ dan $26 \%$. Terdapat hubungan antara stres dengan atensi pada siswa SMA. Perlu dilakukan penelitian lanjutan dengan metode yang berbeda untuk menjelaskan hubungan sebab akibat antara tingkat stres dengan atensi dan variabel lainnya yang berpengaruh terhadap atensi.

\section{UCAPAN TERIMA KASIH}

Penulis menyampaikan terima kasih kepada Kepala sekolah SMA Al-azhar Kelapa gading, SMA Al-chasanah dan seluruh subjek penelitian yang telah bersedia berpartisipasi dalam penelitian ini. 


\section{KONFLIK KEPENTINGAN}

Penulis menyatakan tidak ada konflik kepentingan

\section{KONTRIBUSI KEPENGARANGAN}

Nurhasanah dan Meiyanti berkontribusi pada penulisan naskah, pengumpulan dan analisis data. Meiyanti berkontribusi pada perbaikan naskah. Semua penulis telah membaca naskah terakhir dan memberikan persetujuannya.

\section{REFERENSI}

1. Solso RL, Maclin $\mathrm{OH}$, Maclin MK, editors. Cognitive Psychology. 8th ed. United States of America: Pearson; 2007.

2. Coccaro EF, Zagaja C, Chen P, et al. Relationships between perceived emotional intelligence, aggression, and impulsivity in a population-based adult sample. Psychiatry Res. 2016;246:255-260. doi: 10.1016/j.psychres.2016.09.004

3. Lentini B, Margawati A. Hubungan Kebiasaan Sarapan dan Status Dehidrasi Dengan Konsentrasi Berpikir Pada Remaja. Journal of Nutrition College. 2014;3(4):631-7. doi: 10.14710/jnc. v3i4.6862

4. McNeely C, Blanchard J. The teen years explained: A guide to healthy adolescent development [Internet]. Baltimore: Center for Adolescent Health Johns Hopkins Bloomberg School of Public Health; 2009. Available from: https://www. jhsph.edu/research/centers-and-institutes/centerfor-adolescent-health/_docs/TTYE-Guide.pdf

5. Asmika A, Harijanto H, Handayani N. Prevalensi depresi dan gambaran stressor psikolososial pada remaja sekolah menengah umum di wilayah Kotamadya Malang. Jurnal Kedokteran Brawijaya. 2008;24(1):15-21. doi: /10.21776/ ub.jkb.2008.024.01.2

6. Palacios-García I, Villena-Gonzalez M, CamposArteaga G, et al. Immediate effects of psychosocial stress on attention depend on subjective experience and not directly on stress related physiological changes. 2017 Nov:1-27. Available from: https:// www.biorxiv.org/content/10.1101/223909v1

7. Rahmandani A. Pemaafan dan Aspek Kognitif Dari Stres Pada Mahasiswa Jurusan Kebidanan Tingkat Dua. Jurnal Psikologi Undip. 2015;14(2):118-128. doi: $10.14710 /$ jpu.14.2.118-128

8. Ambarwati PD, Pinilih SS, Astuti RT. Gambaran Tingkat Stres Mahasiswa. Jurnal Keperawatan Jiwa [Internet]. 2017;5(1):40-7. Available from: https://jurnal.unimus.ac.id/index.php/JKJ/article/ view/4466

9. Rahmayani RD, Liza RG, Syah NA. Gambaran Tingkat Stress Berdasarkan Stressor Pada Mahasiswa Kedokteran Tahun Pertama Program Studi Profesi Dokter Fakultas Kedokteran Universitas Andalas Angkatan 2017. Jurnal Kedokteran Andalas. 2019;8(1):103-11. doi: 10.25077/jka.v8i1.977

10. Stroudm LR, Foster E, Papandonatos GD, et al. Stress response and the adolescent transition: performance versus peer rejection stressors. Dev Psychopathol. 2009 Winter;21(1):47-68. doi: 10.1017/S0954579409000042

11. Trobjorn T, Wold B. School-related stress, support, and subjective health complaints among early adolescents: a multilevel approach. J Adolesc. 2001 Dec;24(6):701-13. doi: 10.1006/jado.2001.0440

12. Goodyer IM, Bacon A, Ban M, et al. Serotonin transporter genotype, morning cortisol and subsequent depression in adolescents. $\mathrm{Br} \mathrm{J}$ Psychiatry. 2009 Jul;195(1):39-45. doi: 10.1192/ bjp.bp. 108.054775

13. Thapar A, Collishaw S, Pine DS, et al. Depression in adolescence. Lancet. $2012 \mathrm{Mar}$ 17;379(9820):1056-67. doi: 10.1016/S01406736(11)60871-4

14. Liu G, Hu PP, Fan J, et al. Gender differences associated with orienting attentional networks in healthy subjects. Chin Med J (Engl). 2013 Jun;126(12):2308-12. PubMed PMID: 23786944

15. Nuryana A, Purwanto S. Efektifitas brain gym dalam meningkatkan konsentrasi belajar pada anak. Indigenous: Jurnal Ilmiah Psikologi [Internet]. $2010 \mathrm{Mei} ; 12(1): 88-99$. Available from: http://journals.ums.ac.id/index.php/indigenous/ article/view/1558

16. Rohleder N, Nater UM. Determinants of salivary alpha-amylase in humans and methodological considerations. Psychoneuroendocrinology. 2009 May;34(4):469-85. doi: 10.1016/j. psyneuen.2008.12.004

17. Sutherland M. R., Mather M. Negative arousal amplifies the effects of saliency in short-term memory. Emotion. 2012 Dec;12(6):1367-72. doi: $10.1037 / \mathrm{a} 0027860$

18. Hotulainen R, Sajaniemi N, Suhonen E, et al. Changes and stability in daily cortisol values and their correlation to attention measured in a prolonged working task among Finnish six-yearold day-care children. J Child Adolesc Behav. 2014;2(5):1-8. doi:10.4172/2375-4494.1000168.

19. Arnsten AF. Stress signalling pathways that impair prefrontal cortex structure and function. Nat Rev Neurosci. 2009 Jun;10(6):410-22. doi: 10.1038/ nrn2648. 